\title{
APPLICATION OF DEVICES FOR SPACE-RESOLVED SPECTROSCOPY ON THE EXAMPLE OF TWO-LAYER PHANTOMS CONTAINING METALLIC NANOPARTICLES
}

\author{
Kholodtsova M.N. ${ }^{1,2,3}$, Grachev P.V. ${ }^{1}$, Blondel W.C. ${ }^{2,3}$, Zelenkov P.V. ${ }^{4}$, Potapov A.A. ${ }^{4}$, \\ Shcherbakov I.A. ${ }^{1}$, Loschenov V.B. ${ }^{1,5}$ \\ 'Prokhorov General Physics Institute of the Russian Academy of Sciences, Moscow, Russia \\ ${ }^{2}$ University of Lorraine, Vandoeuvre-les-Nancy, France \\ ${ }^{3}$ CRAN, Nancy, France \\ ${ }^{4}$ N.N. Burdenko National Scientific and Practical Center for Neurosurgery, Moscow, Russia \\ ${ }^{5}$ National Research Nuclear University MEPhl, Moscow, Russia
}

\begin{abstract}
The abilities of the optical probe for fluorescence-guided stereotactic biopsy were investigated by means of a multifiber probe under 532 or $632.8 \mathrm{~nm}$ excitation. The set of multilayered phantoms representing a border between normal brain-tissue and a tumor with photosensitizer and gold nanoparticles (spheres or stars) in different concentrations were made to investigate the macroscopic parameters observed during the neurosurgical biopsy sample collection by means of the optical probe. These investigantions will allow to define the border of a brain tumor and control the type of tissue being collected by a stereotactic cannula during surgery. The impact of gold nanospheres and gold nanostars added in different concentrations to the bottom-layer of phantom was analyzed by fluorescence quenching or enhancement due to energy transfer between nanoparticles and fluorescent molecules. The results allow determining the tumor border and to make the biopsy uptake more efficient by observing the character of signal change while penetrating a tumor and while going out of it.
\end{abstract}

Keywords: plasmon resonance, metal nanoparticles, optical probing depth, fluorescence probing depth, glial tumours, biological tissue, multilayered tissue, spatially resolved spectroscopy, 5-aminolevulinic acid, protoporphyrin IX, stereotactic biopsy, fluorescence spectroscopy.

For citations: Kholodtsova M.N., Grachev P.V., Blondel W.C., Zelenkov P.V., Potapov A.A., Shcherbakov I.A., Loschenov V.B. Spatially-resolved optical spectroscopy abilities of stereotactic biopsy cannula verified by optical multi-fibre probe on two-layered phantoms containing metal nanoparticles for fluorescence enhancement or quenching, Biomedical Photonics, 2018, T. 7, No. 2, pp. 4-12. doi: 10.24931/2413-9432-2018-72-4-12.

Contacts: Kholodtsova M.N., e-mail: m.kholodtsova@gmail.com

\section{ПРИМЕНЕНИЕ УСТРОЙСТВ ДЛЯ ПРОСТРАНСТВЕННО-РАЗРЕШЕННОЙ СПЕКТРОСКОПИИ НА ПРИМЕРЕ ДВУХСЛОЙНЫХ ФАНТОМОВ, СОДЕРЖАЩИХ МЕТАЛЛИЧЕСКИЕ НАНОЧАСТИЦЫ}

М.Н. Холодцова ${ }^{1,2,3}$, П.В. Грачев ${ }^{1}$, В.С. Блондель ${ }^{2,3}$, П.В. Зеленков ${ }^{4}$, А.А. Потапов ${ }^{4}$, И.А. Щербаков', В.Б. Лощенов ${ }^{1,5}$

'Институт общей физики им. А.М. Прохорова РАН, Москва, Россия

2 Университет Лорэйн, Вандёвр-ле-Нанси, Франция

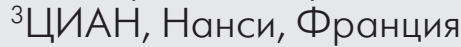

${ }^{4}$ Научно-исследовательский центр нейрохирургии им. акад. Н.Н. Бурденко, Москва, Россия

${ }^{5}$ Национальный исследовательский ядерный университет МИФИ, Москва, Россия

\section{Резюме}

Исследованы возможности применения зонда для стереотаксической биопсии при флуоресцентной навигации при возбуждении 532 или 632,8 нм. Для исследования макроскопических параметров, наблюдаемых во время забора образцов при стереотаксической биопсии с помощью оптического зонда, был сделан набор полужидких, полутвердых многослойных фантомов, моделирующих 
границу между нормальной мозговой тканью и опухолью с фотосенсибилизатором и наночастицами золота (сферы и звезды) в различных концентрациях. Было проанализировано влияние золотых наносфер и нанозвезд, добавленных в разных концентрациях к нижнему слою фантома, на усиление флуоресценции за счет переноса энергии между наночастицами и флуоресцентными молекулами. Результаты позволяют определить границу опухоли и повысить эффективность биопсии, наблюдая характер изменения флуоресцентного сигнала при прохождении зонда через опухоль.

Ключевые слова: плазмонный резонанс, наночастицы металлов, глубина оптического зондирования, глубина зондирования флуоресценции, глиальные опухоли, биологическая ткань, многослойная ткань, пространственно разрешенная спектроскопия, 5-аминолевулиновая кислота, протопорфирин IX, стереотактическая биопсия, флуоресцентная спектроскопия

Для цитирования: Холодцова М.Н., Грачев П.В., Блондель В.С., Зеленков П.В., Потапов А.А., Щербаков И.А., Лощенов В.Б. Возможности пространственно-разрешенной оптической спектроскопии стереотактической канюли для биопсии подтвержденные оптическим многоволоконным зондом на двухслойных фантомах, содержащих металлические наночастицы для усиления или тушения флуоресценции. // Biomedical Photonics. - 2018 - Т. 7, № 2 - С. 4-12. doi: 10.24931/2413-9432-2018-7-2-4-12.

Контакты: Холодцова M.Н., e-mail: m.kholodtsova@gmail.com

\section{Introduction}

In recent years the nanosized materials has been deeply investigated and reached outstanding facilities in preparation of nanoparticles (NP) [1], their use in many areas of nowadays life [2]. Among all NP practical usages and theoretical researches there is one quite prominent, which is connected with inner properties of the material from which NP are made of. Some materials have such properties as having the size below around $100 \mathrm{~nm}$ they have abilities to resonantly absorb and scatter light on a certain wavelength which is defined by the surrounding medium and the geometry of a NP [3]. Applied to photodiagnosis of biological tissue, this kind of NP seems to be leading to the new approaches in fluorescent diagnosis.

The use of plasmonic NP to improve optical properties of biological tissue is of certain interest for biomedical optics. NP could be functionalized with transport agents to accumulate in tumorous tissue, thus improving spectroscopic signal, as NP can be tuned to have enhanced optical properties in special range. This effect has been taken into account by change of optical properties, assuming the NP presence [4].

Recently we had developed a new device for clinical use - the stereotactic biopsy cannula equipped with optical fibers (or the optical biopsy probe). The optical biopsy probe allows simultaneous sampling and spectroscopic analysis of brain tissue during biopsy uptake procedure [5]. This biopsy probe was already tested experimentally by two different wavelengths: 405 and $633 \mathrm{~nm}$ [6].

To expand the area of optical biopsy probe application we conducted a research to investigate its tumor detection abilities not only by fluorescent signal, but also by presence of metal nanoparticles (MNP).

Thus, in the present research we investigate its tumor border detection abilities by fluorescent signal, diffuse reflected light and their ratio on specially developed multi-layered phantoms. The spatially resolved measurements were performed with multifiber probe [7] gives the possibility of optical biopsy probe signal description in terms of spatial resolution and signal enhancement or quenching due to metal NP presence.

The experiment was conducted on the multi-layered phantoms set to recover the signal components collected by optical biopsy probe while penetrating into brain tissue and its influence on fluorescence signal, diffuse reflected light and their ratio. Our experiment involved the use of special MNP, which were added at different concentrations to one of the layers. The influence of MNP on biological tissue optical parameters was investigated. As fluorescent agent protoporphyrin IX (PPIX) was used, because for the fluorescence-guided neurosurgery operations 5-aminolevulinic acid application is usually used to increases accumulation of PPIX in areas which have an increased metabolic activity and correspond to tumor lesions [8].

Firstly, NP were analyzed by spectrophotometry and dynamic light scattering measurements. Secondly, the optical properties of biological tissue were modelled and verified by means of spectrophotometry. Then the spatially and spectrally-resolved diffuse-reflected and fluorescence spectra were obtained by means of multifiber optical probe. The analysis of each fiber contribution into optical biopsy probe signal while penetrating and going out the layer modelling tumorous tissue was done. Such investigation offers possibilities to define the border of tumor while biopsy procedure.

\section{Materials and methods \\ Optical properties of phantoms and NP}

To estimate absorption of NP and optical properties of phantoms components, the spectrophotometer U-3400 (Hitachi, Japan) was used. Spectrophotometer allows determining light attenuation in turbid media by measuring the transmitted light. The measurements were taken for the following NP: gold nanospheres (GNP [9]), gold nanostars (GNS [10]) 


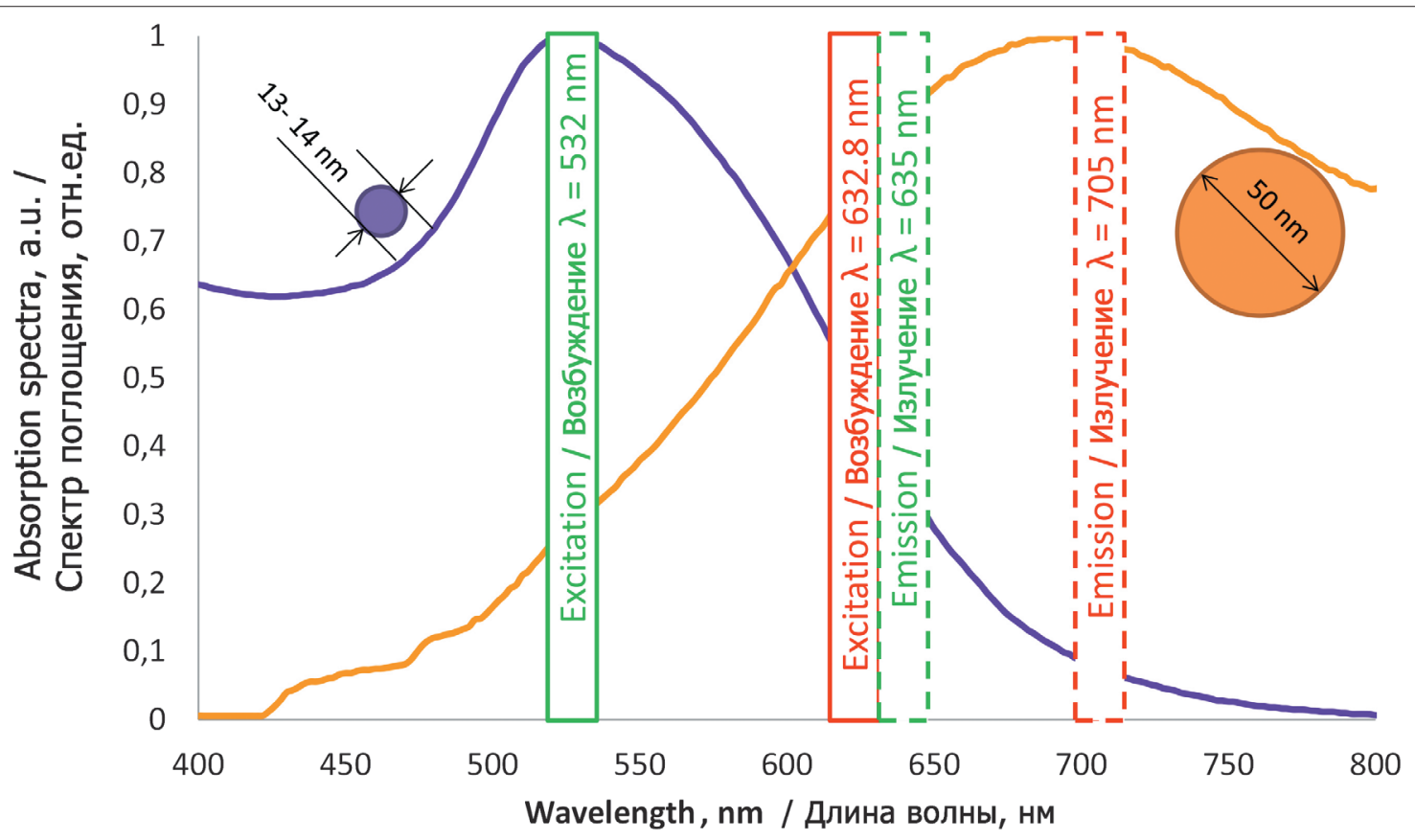

_Excitation / Возбуждение $532 \mathrm{~nm}$

Excitation / Возбуждение $632.8 \mathrm{~nm}$

- Emission / Излучение (532 $\mathrm{nm})$

- Emission / Излучение $(632.8 \mathrm{~nm})$

_Au Nanospheres / Золотые наносферы

Au Nanostars / Золотые нанозвезды

Fig. 1. Absorption spectra of gold nanospheres and nanostars used in the experiments on phantoms. Excitation and fluorescence bands of PPIX

Рис. 1. Спектр поглощения золотых наносфер и нанозвезА, используемых Аля приготовления фантомов. Аиапазоны возбуждения и флуоресценции протопорфирина IX

Fig. 1 is representing the absorption spectra of NP, excitation and emission wavelengths of PPIX. Absorption peak of GNP corresponds to $532 \mathrm{~nm}$ excitation, it was chosen for transferring the energy from GNP to molecules of PPIX. Absorption peak of GNS corresponds to maximum emission wavelength of PPIX. Thus, the GNP intensify the absorption of $532 \mathrm{~nm}$ and the stars intensify the luminescence of PPIX [11-13].

NP size measurements with Photon-Correlation Spectroscopy (PCS)

To measure NP size, the PCS technique with help of multi-angle dynamic and static light scattering instrument Complex (Photocor, Russia) was used. The honiophotometer was fixed on a single angle of $30^{\circ}$ and signal was collected during $2 \mathrm{~min}$.

\section{Modelling optical properties of tissue}

As the biopsy probe was made for parenchymal organs analysis, the phantoms were made to mimic one of tumor types (meningioma or astrocytoma) and normal brain tissue: white or gray matter.

A group of Zaccanti has been working with Indian ink as the absorber which is close to melanin [14]. This group as well has suggested intralipid as the optical standard for making phantoms $[15,16]$. The main absorber in the bottom layer was PPIX and the scatter intralipid. The superficial layer has a variable thickness (0:100:400 $\mu \mathrm{m})$ and was liquid, it consists of intralipid and Indian ink. In this case, blood absorption is modeled with the help of Indian ink. Optical properties of biological tissues are listed in the table 1.

\section{Preparation of phantoms}

The phantoms were made semi-liquid, semi-solid to avoid diffusion between two layers. The phantom components were placed in cubic clean and dry plastic cuvettes. The top-layer was prepared by simple mixing of distilled water, intralipid $10 \%$ and India ink. The bottomlayer was made with gelatin $5 \%$ not overcoming $30^{\circ} \mathrm{C}$ while melting the gelatin in magnetic thermal mixer, these phantoms were kept in fridge under the temperature $2^{\circ} \mathrm{C}$ for about $20 \mathrm{~min}$ to let gelatin congeal. Electronic scales with $0.05 \mathrm{mg}$ precision used for the weight measurements of PPIX and gelatin.

Finally, the concentration of components and the geometry of each layer are presented in the table 2 and on the fig. 2. 
Table 1

Optical properties of white, gray matter of human brain and human tumors (astrocytoma and meningioma) [17, 18], prepared phantoms

\section{Таблица 1}

Оптические свойства приготовленных фантомов белого, серого вещества и опухолей (астроцитома и менингиома) человеческого мозга [17-18]

\begin{tabular}{|c|c|c|c|c|c|}
\hline $\begin{array}{l}\text { Tissue } \\
\text { Tкань }\end{array}$ & $\begin{array}{c}\text { Wave- } \\
\text { length, nm } \\
\text { Длина } \\
\text { волны, нм }\end{array}$ & $\begin{array}{l}\text { Scattering coef- } \\
\text { ficient, } \mathbf{c m}^{-1} \\
\text { Коэффициент } \\
\text { рассеяния, см }{ }^{-1}\end{array}$ & $\begin{array}{l}\text { Absorption coef- } \\
\text { ficient, } \mathbf{c m}^{-1} \\
\text { Коэффициент } \\
\text { поглощения, } \mathrm{cm}^{-1}\end{array}$ & $\begin{array}{c}\text { Anisotropy factor, } \\
\text { Фактор } \\
\text { анизотропии }\end{array}$ & $\begin{array}{c}\text { Transmittance } \\
\text { coefficient, } \mathbf{c m}^{-1} \\
\text { Коэффициент } \\
\text { пропускания, см-1 }\end{array}$ \\
\hline $\begin{array}{l}\text { Gray matter } \\
\text { Cерое вещество }\end{array}$ & \multirow{6}{*}{532} & 100 & 0.60 & 0.87 & 13.6 \\
\hline $\begin{array}{l}\text { White matter } \\
\text { Белое вещество }\end{array}$ & & 450 & 1.00 & 0.83 & 77.5 \\
\hline $\begin{array}{l}\text { Meningioma } \\
\text { Менингиома }\end{array}$ & & 140 & 1.00 & 0.95 & 8.0 \\
\hline $\begin{array}{l}\text { Astrocytoma } \\
\text { Астроцитома }\end{array}$ & & 110 & 1.00 & 0.94 & 7.6 \\
\hline $\begin{array}{l}\text { Phantom top-layer } \\
\text { Верхний слой фантома }\end{array}$ & & 60 & 0.11 & 0.85 & 9.1 \\
\hline $\begin{array}{l}\text { Phantom bottom-layer } \\
\text { Нижний слой фантома }\end{array}$ & & 80 & 2.50 & 0.85 & 14.5 \\
\hline $\begin{array}{l}\text { Gray matter } \\
\text { Серое вещество }\end{array}$ & \multirow{6}{*}{632.8} & 90 & 0.20 & 0.88 & 11.0 \\
\hline $\begin{array}{l}\text { White matter } \\
\text { Белое вещество }\end{array}$ & & 420 & 1.00 & 0.84 & 68.2 \\
\hline $\begin{array}{l}\text { Meningioma } \\
\text { Менингиома }\end{array}$ & & 105 & 0.50 & 0.95 & 5.8 \\
\hline $\begin{array}{l}\text { Astrocytoma } \\
\text { Астроцитома }\end{array}$ & & 200 & 1.00 & 0.95 & 10.1 \\
\hline $\begin{array}{l}\text { Phantom top-layer } \\
\text { Верхний слой фантома }\end{array}$ & & 40 & 0.08 & 0.83 & 6.9 \\
\hline $\begin{array}{l}\text { Phantom bottom-layer } \\
\text { Нижний слой фантома }\end{array}$ & & 50 & 1.00 & 0.83 & 9.5 \\
\hline
\end{tabular}

Table 2

Multi-layered phantoms optical and geometry properties

Таблица 2

Оптические и геометрические параметры многослойных фантомов

\begin{tabular}{|c|c|c|}
\hline $\begin{array}{l}\text { Layer properties } \\
\text { СВойства слоя }\end{array}$ & $\begin{array}{l}\text { Top-layer } \\
\text { Верхний слой }\end{array}$ & $\begin{array}{l}\text { Bottom-layer } \\
\text { Нижний слой }\end{array}$ \\
\hline $\begin{array}{l}\text { Thickness } \\
\text { Толщина }\end{array}$ & $\begin{array}{l}0: 100: 400 \mu \mathrm{m} \\
0: 100: 400 \mu \mathrm{m}\end{array}$ & $\begin{array}{c}\text { Semi-infinite (more than } 3 \mathrm{~cm} \text { ) } \\
\text { Полу-бесконечный (более } 3 \mathrm{~cm} \text { ) }\end{array}$ \\
\hline $\begin{array}{l}\text { Absorber } \\
\text { Поглотители }\end{array}$ & $\begin{array}{l}\text { India ink } 0.02 \% \\
\text { Индиа Инк 0,02\% }\end{array}$ & $\begin{array}{l}\text { Gelatin 5\% } \\
\text { Желатин 5\% }\end{array}$ \\
\hline $\begin{array}{l}\text { Scatterer } \\
\text { Рассеиватели }\end{array}$ & $\begin{array}{c}\text { Intralipid 2\% } \\
\text { Интралипид 2\% }\end{array}$ & $\begin{array}{c}\text { Intralipid 3\% } \\
\text { Интралипид 3\% }\end{array}$ \\
\hline $\begin{array}{l}\text { Nanoparticles } \\
\text { Наночастицы }\end{array}$ & - & $\begin{array}{c}\text { GNP: 0, 1, 2, } 4 \text { mg/kg GNS: 0, } 0.5 \text { mg/kg } \\
\text { 3НC: 0, 1, 2, } 4 \text { мг/кг ЗН3: 0, 0,5 мг/кг }\end{array}$ \\
\hline $\begin{array}{l}\text { Fluorophore } \\
\text { Флуорофор }\end{array}$ & - & $\begin{array}{l}\text { PPIX, } 1 \mathrm{mg} / \mathrm{kg} \\
\text { ППІХ, } 1 \mathrm{Mг} / \mathrm{Kг}\end{array}$ \\
\hline
\end{tabular}

GNP - gold nanospheres

GNS - gold nanostars

PPIX - protoporphyrin IX

ЗНС - золотые наносферы

ЗН3 - золотые нанозвездь

ППІХ - протопорфирин IX 


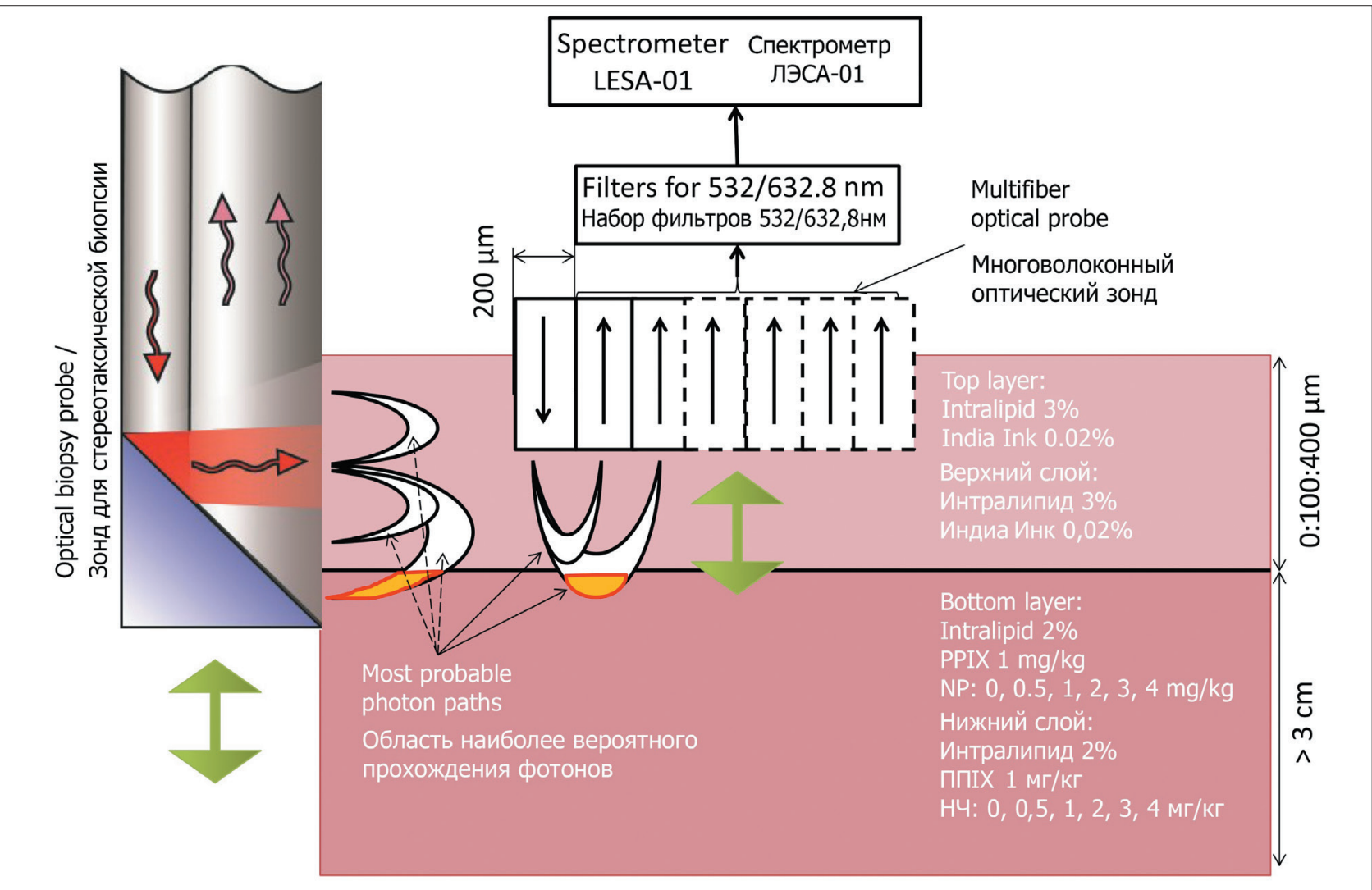

Fig. 2. Sketch of experimental design used to measure optical response of the modelled tissue

Рис. 2. Эскиз экспериментальной установки Аля измерения оптического ответа в приготовленных фантомах

\section{Experimental design}

For GNP and PPIX containing phantoms green diode laser (532 nm, $30 \mathrm{~mW}$ BIOSPEC, Russia) was used. For GNS and PPIX containing phantoms HeNe laser $(632.8 \mathrm{~nm}, 30$ $\mathrm{mW}$ BIOSPEC, Russia) was used. Both lasers correspond to Q-bands of PPIX absorbance. Signal was analyzed by LESA-01-Biospec spectrometer (BIOSPEC, Russia). The multifiber probe with six source-detector separations (SDS) was used. Distances 261, 344, 500, 778, 1041, 1290 $\mu \mathrm{m}$ between source and detector were used for collection the back scattered light. For $532 \mathrm{~nm}$ excitation, the detection range was $500-800 \mathrm{~nm}$, for $632.8 \mathrm{~nm}-600$ $800 \mathrm{~nm}$. The setup and description of the fiber and its parameters are presented on the figure 2 .

Laser is connected to the multifiber probe with six different SDS. The diffuse-reflected light and fluorescent signal are collected by the receiving fibers, then transferred to spectrometer and analyzed by UnoMomento software (BIOSPEC, Russia). The model of tissue is described above. The «banana»-shaped regions drawn under the fibers (fig. 2) are the most probable paths calculated by diffusion approximation to radiation transfer equation and used in our previous work for determining the optical and effective fluorescent probing depth [19-20].

\section{Multifiber optical probe and optical biopsy probe}

The multifiber optical probe used in the experiment was specially developed for multimodal spectroscopy for elastic scattering (or diffuse-reflected) and autofluorescence analysis to characterize biological tissue in vivo and in vitro. Its configuration allows combining the principles of diffuse optical spectroscopy and imaging such as spatial, spectral and depth resolutions combined with light-tissue interaction models.

The multifiber optical probe geometry and main properties are shown on the fig. 3 . It should be mentioned that the light losses were no more than $10 \%$. Maximum output power was $30 \mathrm{~mW}$, estimated losses on the output of the multifiber probe less than $3 \mathrm{~mW}$.

Sketch of the optical biopsy probe is presented on the fig. 2.

\section{Conformity of the multifiber probe and the optical biopsy probe}

First of all, we need to state that we specially use the multifiber probe instead of the optical biopsy probe, because the first one has several SDS whose contribution into signal could be analyzed separately, which is not the case for the biopsy probe, which has more complicated form of the detecting fiber. This special type of aligned 


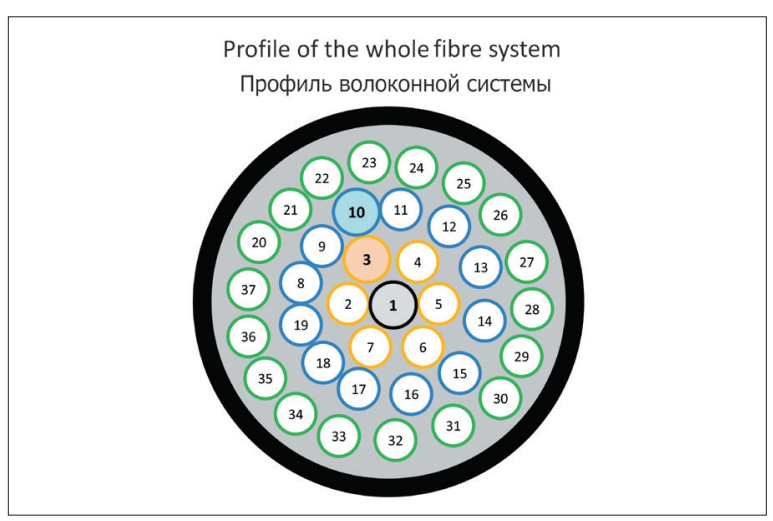

a

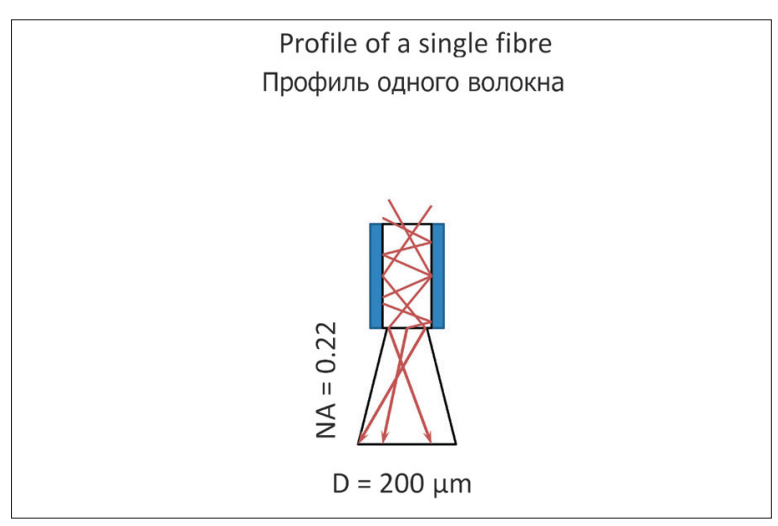

b

Fig. 3. The multifiber optical probe used in the experiment: a - aprofile of single fiber;

b - the whole multifiber optical probe geometry

Рис. 3. Многоволоконный оптический зонд:

а - профиль единичного волокна;

b - геометрия многоволоконного оптического зонда

fiber-detector was specially developed for stereotactic biopsy procedure, which needs the illumination of probing tissue. The multifiber probe is used for the superficial measurements and could be only partly compared to the optical biopsy probe, which is used while penetrating in the brain tissue during the biopsy procedure. In this investigation, our goal is simply to obtain a better biopsy specimen for pathological analysis, that is why we can only compare the two probes, as the multifiber probe shows the contribution of smaller parts of the optical biopsy probe.

The configuration of the optical biopsy probe is different from the one of the multifiber probe used for the measurements, thus it is needed to get the detailed comparison of the spectra which are obtained by both probes. To understand the contribution of fluorescent signal and diffuse reflected signal to spectra obtained by stereotactic biopsy cannula, we first compare the areas from which both devices receive signal. It could be done by analyzing the «banana»-shaped regions. On the fig. 4 there is a schematic representation of the probes fibers conformity.

The fibers used in both probes has the same numerical aperture (NA = 0.22). However, the detector-fiber in the optical biopsy probe is oblique and its diameter is 600 $\mu \mathrm{m}$. Its probing area corresponds twice to the first SDS and once to second SDS of the multifiber probe. When the optical biopsy probe is in the tumor area, SDS are:

1. Fiber №10 - Fiber №3 equals $260.8 \mu \mathrm{m}$,

2. Fiber №31 - Fiber №15 equals $343.6 \mu \mathrm{m}$.

However, when a tissue is examined with optical biopsy probe, it means that the multifiber probe first gains the signal with the fiber placed on the second SDS $(344 \mu \mathrm{m})$.
Then the fiber placed on the first SDS $(261 \mu \mathrm{m})$ starts to contribute in the signal of the cannula which is now represented by the sum of signals from both SDS. Afterwards the signal from the first SDS (344 $\mu \mathrm{m})$ is doubled and the signal collected by the optical biopsy probe is affected by the doubled signal from fiber placed at the first SDS and one from the fiber placed at the second SDS $(261 \mu \mathrm{m})$. Even though the probes are placed differently according to the bottom-layer as it is indicated on the fig. 2 we still

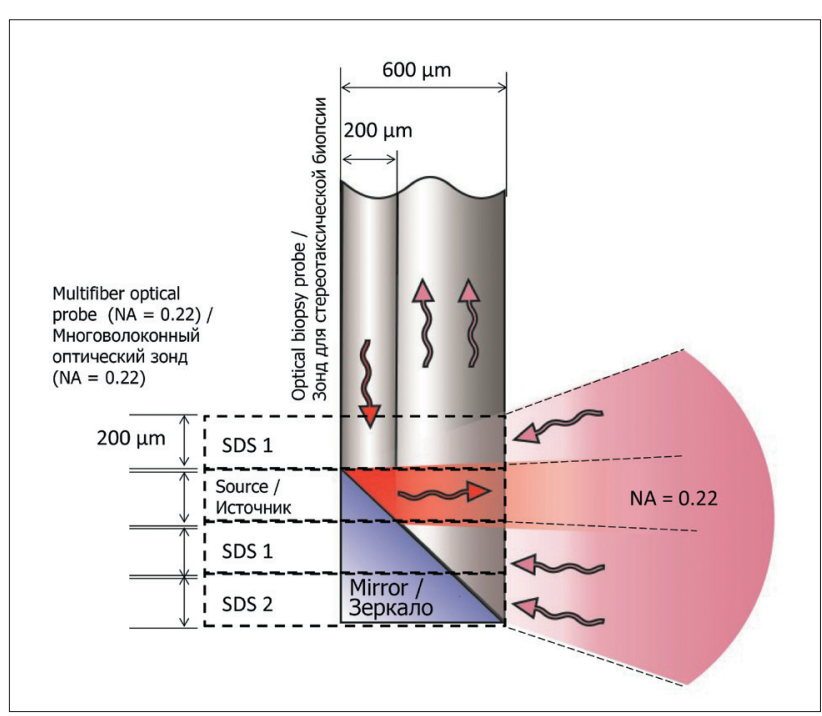

Fig. 4. Conformity between the multifiber probe used in the experiment and the stereotactic biopsy cannula numerical apertures. Dotted lines represent the fibers of a multifiber optical probe

Рис. 4. Соответствие апертур многоволоконного зонда, используемого в эксперименте, и зонда для стереотаксической биопсии. Пунктирными линиями показаны волокна многоволоконного оптического зонда 


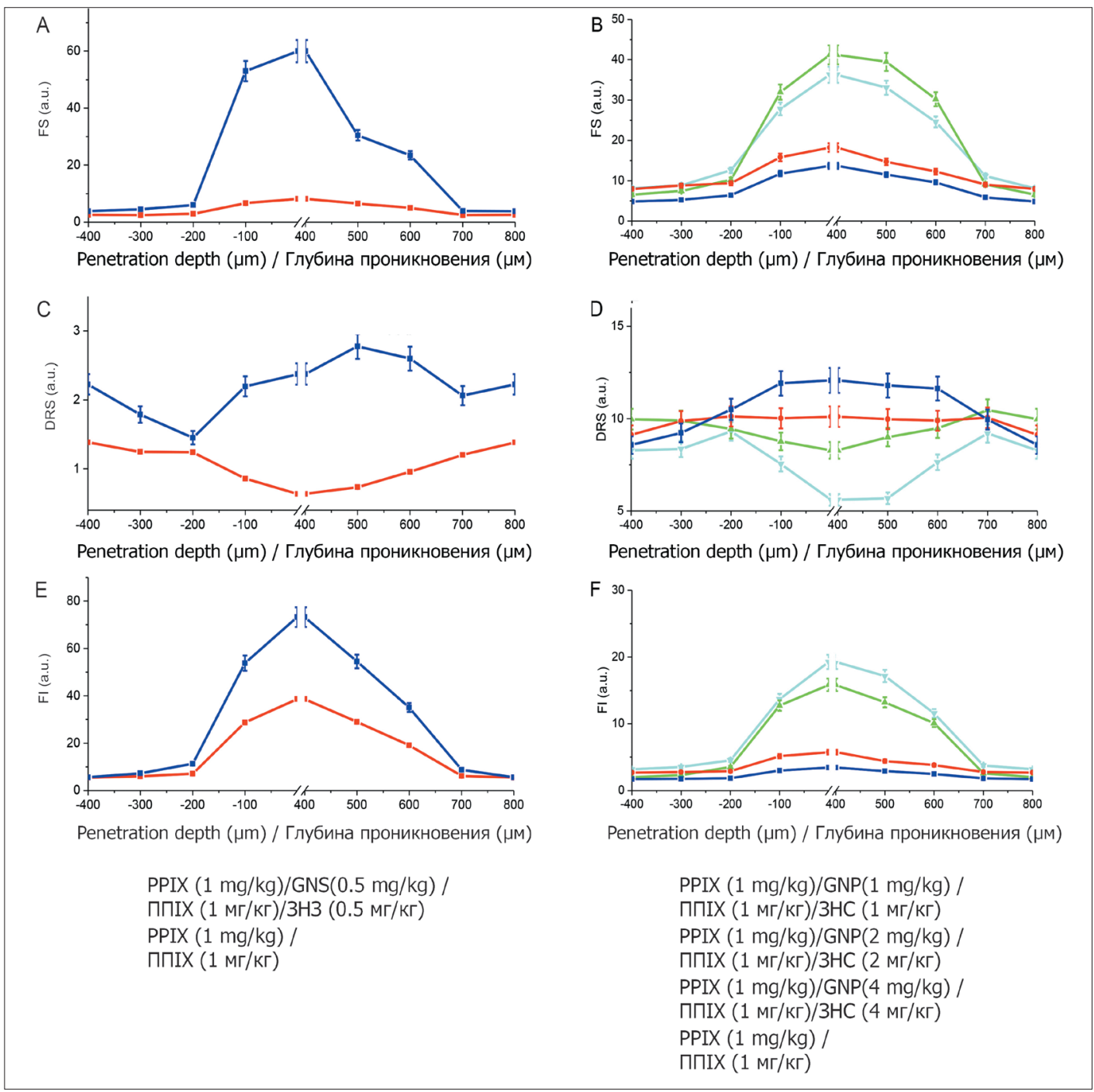

Fig. 5. Influence of concentration and penetration depth on DRS (A, B), FS (C, D) and FI (E, F). Left column is for phantom with GNS, right - phantom with GNP

Рис. 5. Влияние концентрации и глубины проникновения на диффузионно-рассеянный сигна^ DRS (A, B), флуоресцентный сигнал FS (C, D) и индекс флуоресценции FI (E, F). Аевая колонка - фантом с золотыми нанозвезАами (3Н3), правая - с золотыми наносферами (3НС)

can derive the signal, which is obtained when the optical biopsy probe is going out from a tumor. Hereby now the fiber places at the first SDS is leaving the tumor but the major part of 'banana'-shaped region remains in a tumor.

Thus, when the fluorescent signal is gathered by multifiber probe it means that optical biopsy probe is $100 \mu \mathrm{m}$ deep according to the scheme and principle of photons' most probable paths estimation, described elsewhere [19]. Keeping in mind the fig. 2 and yellow areas bordered with red line we say that these areas give the same contribution in diffuse reflected and fluorescence spectra of both probes, however different by absolute value.

\section{Results and discussion}

We used glass round cuvette with diameter $10 \mathrm{~mm}$ for preparation of phantoms. $3.5 \mu \mathrm{l}$ of NP were added to $3 \mathrm{ml}$ of water, gold density was $19.3 \mathrm{~g} / \mathrm{ml}$. Then, number of particles per cubic $\mu \mathrm{m}$ was estimated $3.24^{*} 10^{-3}$. The measured hydrodynamic diameter of the GNP was $14 \mathrm{~nm}$, GNS - 50 $\mathrm{nm}$. It should be noticed that concentration of $1 \mathrm{mg} / \mathrm{kg}$ of GNP gives around 790 particles per $100 \times 100 \times 100 \mu m^{3}, 0.5$ $\mathrm{mg} / \mathrm{kg}$ of GNS - around 395; PPIX concentration of $1 \mathrm{mg} /$ $\mathrm{kg}-1.07^{*} 10^{9}$ particles per same volume.

The group of scientists proposed equation to define the nanoparticle diameter [20]. According to their results, the GNP size was determined as $13.0 \pm 1.4 \mathrm{~nm}$, what corresponds with the result of PCS measurements, which gave 14.0 \pm 1.2 $n m$ diameter. For GNS the equation does not applicable due to their nonspherical form, electron microscopy shows that the particles are around $50 \mathrm{~nm}$ in size.

Spectroscopic studies can be carried out using both a multifiber optical probe and an optical biopsy probe. 
To compare spectroscopic signals from these devices, one must take into account their internal structure. Make the necessary changes in the calculation based on SDS detectors.

The obtained spectra were analyzed separately by the following parameters:

1. Diffuse-Reflected Signal (DRS);

2. Fluorescent Signal (FS);

3. Fluorescence Index (FI), FI = FS/DRS,

where DRS is an area under the spectrum curve in diffuse-reflected laser range wavelength, FS is an area under the spectrum curve in fluorescence range wavelength.

The results are obtained with multifiber optical probe and presented on the fig. 5 . Zero corresponds to the border between top and bottom layers, the break from 0 to $400 \mu \mathrm{m}$ corresponds to thickness of the bottom-layer, which we chose to be $400 \mu \mathrm{m}$, the signal is constant, thus we put a break on the graphs.

The left column of graphs, A, C, E represents FS, DRS and $\mathrm{Fl}$, respectively, while exciting with $632.8 \mathrm{~nm}$ the phantoms, containing GNS $(0,0.5 \mathrm{mg} / \mathrm{kg})$ and PPIX $1 \mathrm{mg} / \mathrm{kg}$.

The right column of graphs, B, D, F represents FS, DRS and $\mathrm{FI}$, respectively, while exciting with $532 \mathrm{~nm}$ the phantoms, containing GNP $(0,1,2,4 \mathrm{mg} / \mathrm{kg})$ and PPIX $1 \mathrm{mg} / \mathrm{kg}$.

The main difference observed for phantoms containing PPIX without NP - the higher FI while exciting with longer wavelength, even though the absorption of PPIX on $632.8 \mathrm{~nm}$ and emission on $705 \mathrm{~nm}$ are lower than absorption on $532 \mathrm{~nm}$ and consequent emission on 635 $\mathrm{nm}$. It could be explained with reabsorption of $635 \mathrm{~nm}$ due to PPIX presence, with higher scattering on lower wavelengths, thus even though the fluorescing centers (PPIX molecules) are excited more efficiently with lower wavelength, the volume excited by longer wavelength is higher, according to scattering and absorption properties of phantoms. From this, we can conclude that the $632.8 \mathrm{~nm}$ excitation is more efficient for optical biopsy.

By the character of the curves we can conclude from which part of the brain the biopsy is taken:

- if the signal is constant (FS, DRS or FI) - the biopsy probe would be taken from the tumor itself,

- while the biopsy probe approaching a tumor the FS and FI start to increase, however the character of decrease while going out of a tumor is different, as the main contribution is given by the second SDS, which is first to approach a tumor and the first to leave it.

- both types of NP showed change in the parameters analyzed less than $300 \mu \mathrm{m}$ away from the border between two layers while the optical biopsy probe approaching it and less than $100 \mu \mathrm{m}$ away from the border while the probe is leaving the layer containing NP.

GNS are drastically changing DRS, FS and consequently $\mathrm{Fl}$ in comparison with pure PPIX phantoms. We can con- clude that FS quenching occurs with efficiency from 1.5 to 8 times. When the optical biopsy probe approaches a tumor containing these NP, they start to absorb and scatter the light, but as it is seen from DRS increase due to presence of GNS (fig. 5C) - the light is mostly scattered which is due to big size of GNS.

Another set of phantoms containing GNP in different concentrations $(1,2,4 \mathrm{mg} / \mathrm{kg})$ being excited close to maximum of transmission showed increase in FS (fig. 5B) and decrease in DRS (fig. 5D). Decrease in DRS is explained due higher absorption to scattering rate of $14 \mathrm{~nm}$ size GNP. This resulted in higher Fl: from 1 to 3.5 times for phantoms containing GNP according to pure phantoms (fig. 5F). The highest concentration of GNP $4 \mathrm{mg} / \mathrm{kg}$ was almost comparable with pure phantoms, the difference observed is no more than $20 \%$, however for $2 \mathrm{mg} / \mathrm{kg}$ of $\mathrm{GNP}$, the difference in $\mathrm{Fl}$ is from 1.8 to 8 times higher and the closer the optical biopsy probe is to the border, the higher is difference between phantoms containing and not containing GNP.

\section{Conclusion}

The working ranges of the photosensitizer PPIX used in the clinical practice were investigated. We used the GNP to increase of the absorption in the $532 \mathrm{~nm}$ wavelength region, and GNS to increase the fluorescence in the 705 $\mathrm{nm}$ wavelength region. Both the multifiber optical probe and an optical biopsy probe can be used to register spectroscopic signals on the boundary of media. The multifiber optical system allows modeling other fiber spectroscopic systems, as well as interpreting spectroscopic data from them in various clinical cases.

GNP concentration of $2 \mathrm{mg} / \mathrm{kg}$ appeared to be the most effective in energy transfer from GNP to PPIX molecules when it is excited to extinction peak of GNP and absorption peak of PPIX simultaneously thus increasing Fl up to 6 times according to the concentration. Thus, we showed that red laser excitation is more efficient than green one, however in vicinity of small gold NP (14 nm) of sufficiently low concentration (1-2 mg/kg) gives fluorescent signal enhancement, while big nanostars $(50 \mathrm{~nm})$ in lower concentration $(0.5 \mathrm{mg} /$ $\mathrm{kg}$ ) are already quenching fluorescent signal.

The results obtained allow determining location of the biopsy optical probe during the stereotactic biopsy procedure.

The work was conducted in the frame of co-supervised PhD thesis between the University of Lorraine, CRAN-CNRS (France, Nancy) and GPI RAS (Russia, Moscow). Kholodtsova M. would like to acknowledge the financial support for PhD grant from Conseil Regional de Lorraine and French Embassy in Moscow.

This work was supported by Russian Ministry of Education and Science [grant number RFMEFI61615X0064]. 


\section{ЛИТЕРАТУРА}

1. Champion J., Katare Y., Mitragotri S. Particle shape: A new design parameter for micro- and nanoscale drug delivery carriers // Journal of Controlled Release. - 2007. - Vol. 121. - P. 3-9.

2. Weibo C., Ting G., Hao H., Sun J. Applications of gold nanoparticles in cancer and nanotechnology // Nanotechnology, Science and Applications. - 2008. - № 1. - P. 17-32.

3. Bohren C., Huffman D. Absorption and Scattering of Light by Small Particles. - Wiley, VCH Verlag GmbH, 1998. - 545 p.

4. Cihan C., Arifler D. Influence of phase function on modeled optical response of nanoparticle-labeled epithelial tissues // Journal of Biomedical Optics. - 2011. - Vol. 16(8). - 085002.

5. Потапов А.А., Гаврилов А.Г.,Горяйнов С.А.идр.Способ проведения интраоперационной комбинированной спектроскопической диагностики опухолей головного и спинного мозга Simultanious parenchymal organ biopsy and spectroscopic inspection device. Патент РФ №2497558, 2013. - 16 c.

6. Markwardt N.A., Haj-Hosseini N., Hollnburger B., et al. $405 \mathrm{~nm}$ versus $633 \mathrm{~nm}$ for protoporphyrin IX excitation in fluorescenceguided stereotactic biopsy of brain tumors // Journal of Biophotonics. - 2015. - Vol. 9(9). - P. 901-912.

7. Blondel W.C., Ghribi M., Leroux A., et al. Spectral features selection and classification for bimodal optical spectroscopy applied to bladder cancer in vivo diagnosis // IEEE Transactions on Biomedical Engineering. - 2014. - Vol 61(1). - P. 207-216.

8. Rick K., Sroka R., Stepp H., Kriegmair M., et al. Pharmacokinetics of 5-aminolevulinic acid-induced protoporphyrin ix in skin and blood // Journal of Photochemistry and Photobiology B-Biology. 1997. - Vol. 40(3). - P. 313-319.

9. Wuithschick M., Birnbaum A., Witte S., et al. Turkevich in new robes: Key questions answered for the most common gold nanoparticle synthesis // ACS Nano. - 2015. - Vol. 9(7). - P. 7052-7071.

10. Hrelescu C., Sau T.K. Selective excitation of individual plasmonic hotspots at the tips of single gold nanostars // Nano Letters. 2011. - Vol. 11. - P. 402-407.

11. Scaffard L., Tocho J. Size dependence of refractive index of gold nanoparticles // Nanotechnology. - 2006. - Vol. 17. - P. 1309-1315.

12. Kholodtsova M., Samsonova I., Blondel W., Loschenov V. Metal nanoparticles of different shapes influence on optical properties of multilayered biological tissues // Proceedings of SPIE. -2015. Vol. 9542. - 954205.

13. Kang K., Wang J., Jasinski J., Achilefu S. Fluorescence manipulation by gold nanoparticles: From complete quenching to extensive enhancement // Journal of Nanobiotechnology. - 2011. - Vol. 9. - P. 16.

14. Ninni P.D., Martelli F., Zaccanti G. The use of India Ink in tissue-simulating phantoms // Optics Express. - 2010. - Vol. 18(26). - P. 26854 26865.

15. Ninni P.D., Martelli, F., Zaccanti G. Intralipid: towards a diffusive reference standard for optical tissue phantoms // Physics in Medicine and Biology. - 2011. - Vol. 56. - P. 21-28.

16. Flock S.T., Jacques S.L., Wilson B.C., et al. Optical properties of intralipid: A phantom medium for light propagation studies // Lasers in Surgery and Medicine. - 1992. - Vol. 12(5) - P.510-519.

17. Yaroslavsky N., Schulze P., Yaroslavsky I.V., et al. Optical properties of selected native and coagulated human brain tissues in vitro in the visible and near infrared spectral range // Physics in Medicine and Biology. - 2002. - Vol. 47(12). - P. 2059-2073.

18. Bashkatov, A., Genina, E., Tuchin, V., Optical properties of skin, subcutaneous, and muscle tissues: a review // Journal of Innovative Optical Health Science. - 2011. - Vol. 04(01). - P.9-38.

19. Kholodtsova M.N., Grachev P.V., Savelieva T.A., et al. Scattered and fluorescent photon track reconstruction in a biological tissue // International Journal of Photoenergy. - 2014. - 517510

20. Haiss W., Thanh N., Aveyard J., Fernig, D. Determination of size and concentration of gold nanoparticles from uv-vis spectra // Analytical Chemistry. - 2007. - Vol. 79. - P.4215-4221.

\section{REFERENCES}

1. Champion J., Katare Y., Mitragotri S. Particle shape: A new design parameter for micro- and nanoscale drug delivery carriers, Journal of Controlled Release, 2007, Vol. 121, pp. 3-9.

2. Weibo C., Ting G., Hao H., Sun J. Applications of gold nanoparticles in cancer and nanotechnology, Nanotechnology, Science and Applications, 2008, No. 1, pp. 17-32.

3. Bohren C., Huffman D. Absorption and Scattering of Light by Small Particles. Wiley, VCH Verlag GmbH, 1998. 545 p.

4. Cihan C., Arifler D. Influence of phase function on modeled optical response of nanoparticle-labeled epithelial tissues, Journal of Biomedical Optics, 2011, Vol. 16(8), 085002.

5. Potapov A.A., Gavrilov A.G., Goryaynov S.A., Zelenkov P.V., Gol'bin D.A., Savel'eva T.A. et al.Sposob provedeniya intraoperatsionnoykombinirovannoy spektroskopicheskoy diagnostiki opukholey golovnogo i spinnogo mozga [Simultanious parenchymal organ biopsy and spectroscopic inspection device]. Patent RF no. 2497558, 2013. 16 p.

6. Markwardt N. A., Haj-Hosseini N., Hollnburger B., Stepp, H., Zelenkov, P., Ruhm A. $405 \mathrm{~nm}$ versus $633 \mathrm{~nm}$ for protoporphyrin IX excitation in fluorescence-guided stereotactic biopsy of brain tumors, Journal of Biophotonics, 2015, Vol. 9(9), pp. 901-912.

7. Blondel W.C., Ghribi M., Leroux A., Pery E., Tindel S. Spectral features selection and classification for bimodal optical spectroscopy applied to bladder cancer in vivo diagnosis, IEEE Transactions on Biomedical Engineering, 2014, Vol 61(1), pp. 207-216.

8. Rick K., Sroka R., Stepp H., Kriegmair M., Huber R.M., Jacob K., Baumgartner R. Pharmacokinetics of 5-aminolevulinic acidinduced protoporphyrin ix in skin and blood, Journal of Photochemistry and Photobiology B-Biology, 1997, Vol. 40(3), pp. 313-319.

9. Wuithschick M., Birnbaum A., Witte S., Sztucki M., Vainio U., Pinna N., Rademann K., Emmerling F., Kraehnert R., Polte J. Turkevich in new robes: Key questions answered for the most common gold nanoparticle synthesis, ACS Nano, 2015, Vol. 9(7), pp. 7052-7071.

10. Hrelescu C., Sau T.K. Selective excitation of individual plasmonic hotspots at the tips of single gold nanostars, Nano Letters, 2011, Vol. 11, pp. 402-407.

11. Scaffard L., Tocho J. Size dependence of refractive index of gold nanoparticles, Nanotechnology, 2006, Vol. 17, pp. 1309-1315.

12. Kholodtsova M., Samsonova I., Blondel W., Loschenov V. Metal nanoparticles of different shapes influence on optical properties of multilayered biological tissues, Proceedings of SPIE, 2015, Vol. 9542, 954205

13. Kang K., Wang J., Jasinski J., Achilefu S. Fluorescence manipulation by gold nanoparticles: From complete quenching to extensive enhancement, Journal of Nanobiotechnology, 2011, Vol. 9, p. 16.

14. Ninni P.D., Martelli F., Zaccanti G. The use of India Ink in tissue-simulating phantoms, Optics Express, 2010, Vol. 18(26), pp. 26854-26865.

15. Ninni P.D., Martelli, F., Zaccanti G. Intralipid: towards a diffusive reference standard for optical tissue phantoms, Physics in Medicine and Biology, 2011, Vol. 56, pp. 21-28.

16. Flock S.T., Jacques S.L., Wilson B.C., Star W.M., van Gemert M.J. Optical properties of intralipid: A phantom medium for light propagation studies, Lasers in Surgery and Medicine, 1992, Vol. 12(5), pp. 510-519.

17. Yaroslavsky N., Schulze P., Yaroslavsky I.V., Schober R., Ulrich F., Schwarzmaier H.J. Optical properties of selected native and coagulated human brain tissues in vitro in the visible and near infrared spectral range, Physics in Medicine and Biology, 2002, Vol. 47(12), pp. 2059-2073.

18. Bashkatov, A., Genina, E., Tuchin, V., Optical properties of skin subcutaneous, and muscle tissues: a review, Journal of Innovative Optical Health Science, 2011, Vol. 04(01), pp. 9-38.

19. Kholodtsova M.N., Grachev P.V., Savelieva T.A., Kalyagina N.A., Blondel W., Loschenov V.B. Scattered and fluorescent photon track reconstruction in a biological tissue, International Journal of Photoenergy, 2014, 517510.

20. Haiss W., Thanh N., Aveyard J., Fernig, D. Determination of size and concentration of gold nanoparticles from uv-vis spectra, Analytical Chemistry, 2007, Vol. 79, pp. 4215-4221. 